\title{
Pd-Catalyzed Suzuki-Miyaura couplings and evaluation of 13a-estrone derivatives as potential anticancer agents
}

Rebeka Jójárt, ${ }^{1, a}$ Hazhmat Ali, ${ }^{2, a}$ Gergely Horváth, ${ }^{1}$ Zoltán Kele, ${ }^{3}$ István Zupkó, ${ }^{2 *}$ Erzsébet Mernyák $^{1 *}$

${ }^{1}$ Department of Organic Chemistry, University of Szeged, Dóm tér 8, H-6720 Szeged, Hungary ${ }^{2}$ Department of Pharmacodynamics and Biopharmacy, University of Szeged, Eötvös u. 6., H6720 Szeged, Hungary

${ }^{3}$ Department of Medicinal Chemistry, University of Szeged, Dóm tér 8, H-6720 Szeged, Hungary

*Corresponding authors. Tel.: +36 62 544277; fax: +36 62544200 (E. Mernyák).

E-mail addresses: bobe@chem.u-szeged.hu (E. Mernyák).

${ }^{\text {aT }}$ These authors contributed equally to this work.

\begin{abstract}
$13 \alpha$-Estrones are of great value owing to their potent multiple bioactivity, including anticancer activity. $3-\mathrm{OH}$ or $3-\mathrm{OBn}$ derivatives of 2 - or $4-[($ subst.) phenyl]-13 $\alpha$-estrone as potential antiproliferative agents have been synthesized via facile, microwave-induced, Pd-catalyzed Suzuki-Miyaura coupling. 2- or 4-Halogenated 13 $\alpha$-estrone derivatives have been reacted with (4-subst.)phenylboronic acids using $\mathrm{Pd}\left(\mathrm{PPh}_{3}\right)_{4}$ as catalyst. The nature of para substituents at the introduced phenyl group did not influence the outcome of couplings. Certain newly synthesized compounds displayed substantial antiproliferative action against human adherent cancer cell lines of gynecological origin. Important structure-activity relationships were revealed, which might be helpful in the design of potent and selective anticancer derivatives based on the hormonally inactive $13 \alpha$-estrane core.
\end{abstract}

Keywords: Suzuki-Miyaura coupling, 13 $\alpha$-estrone, phenylboronic acid, anticancer, MCF-7, Hela.

\section{Introduction}

The primary function of female sex hormones (estrogens) is to facilitate the development of female secondary sexual characteristics and to control the reproductive functions [1]. However, certain estrogens possess other biological activities, including anti-angiogenic, neuroprotective, anticancer effects and others [2]. Despite the known property of $17 \beta$-estradiol promoting cell 
proliferation, its derivatives might act as antiproliferative agents [3]. The major risk in the design of anticancer agents based on the estrane core is the potential hormonal side effect of the lead compound. One possibility for minimizing the undesirable estrogenic behavior is the transformation of natural estrogens into their core-modified analogs [4-6]. 13 $\alpha$-Estrone (1a) is an epimer of natural estrone (Figure 1) [4]. The inversion of the configuration at C-13 results in a modified conformation, and that is why $13 \alpha$-estrone and its 17 -ol derivatives do not possess estrogenic behavior [7]. Considering that $13 \alpha$-estrone (1a) is readily available in a single step from its natural counterpart, it might serve as a promising candidate for the design of anticancer compounds lacking hormonal action. We have demonstrated recently that this group of synthetic compounds offers great possibilities concerning bioactivity [8-10]. It was shown that certain structurally different enzymes involved in estrogen biosynthesis $[11,12]$ can be inhibited by 2 - and/or 4 -substitued 13 $\alpha$-estrone derivatives (Figure 2, compound I). The most potent inhibitors displayed $\mathrm{IC}_{50}$ values in ranges similar to those of their $13 \beta$ counterparts.

It should be highlighted that organic anion transporter protein OATP2B1, one of the key players in intestinal drug absorption and drug transport, can also be inhibited by $13 \alpha$-estrone compounds (Figure 2, compound 3a) [13]. The observed inhibitory potencies are comparable to those of the best OATP2B1 inhibitors ever published.

Figure 1.

Not only enzyme inhibitory behavior, but the direct antiproliferative potential of certain $13 \alpha-$ estrones have also been published by our group [14-20]. Certain C-3-O and C-16 modified derivatives (Figure 2, compound II [14]) displayed outstanding cell growth-inhibitory action against a range of human adherent cancer cell lines. Investigations of the mechanism of action revealed that compound II indicated cell cycle blockade at the G2-M transition. Caspase activity determinations proved that the compound induced apoptosis via the intrinsic pathway.

Figure 2.

The above-mentioned literature data suggest that $13 \alpha$-estrones are of great value owing to their potent multiple bioactivity without estrogenic side effects. 
The Suzuki-Miyaura reaction is a palladium-catalyzed cross-coupling between organic boron compounds and organic halides [21,22]. It requires the addition of a base for activation of a boron reagent. The $\mathrm{C}\left(\mathrm{sp}^{2}\right)-\mathrm{C}\left(\mathrm{sp}^{2}\right)$ coupling proceeds under mild conditions and tolerates a wide range of functional groups. This methodology is a very powerful tool for diaryl formation, including the synthesis of pharmaceuticals and complex natural products.

Literature reveals the application of Suzuki-Miyaura coupling in the synthesis of estrone derivatives with diverse biological activities. $\mathrm{C}-\mathrm{C}$ couplings on the estrane core were carried out mainly at C-2, C-3, C-4 or C-17 [23-29]. Estrone derivatives such as aryl halides (at C-2 or C-4) or aryl or enol triflates (at C-3 or C-17) have been used. However, Ciana et al. developed a copper-catalyzed, site-selective $\mathrm{C}-\mathrm{H}$ arylation methodology for the synthesis of 2-phenyl estrone derivatives [30]. Sato et al. synthesized estrone-isoquinoline hybrids as cortistatin analogs with substantial anti-angiogenic properties [23]. 17-Pyridyl estrones have been prepared as effective AKR1C3 inhibitors, which might be promising drug candidates in the treatment of endometriosis. Suzuki couplings at C-3 resulted in estrone derivatives as covalent 17ß-HSD1 inhibitors [24]. Langer et al. published recently the synthesis of 2- and/or 4arylestrones via $\mathrm{C}-\mathrm{C}$ coupling. Certain 4-aryl regioisomers proved to be potent pancreatic lipase inhibitors [25]. Poirier et al. demonstrated that estrone derivatives bearing 2(subst.)phenyl ring possess substantial cytochrome P450 (CYP) 1B1 inhibitory activity [29].

Based on the above-mentioned literature results, here we intended to perform Suzuki-Miyaura couplings on the hormonally inactive $13 \alpha$-estrane core. Regarding the promising biological properties of derivatives modified on ring A, C-2 and C-4 have been chosen as subjects for modifications. Our aim was to synthesize 3-hydroxy and 3-benzyloxy 2- or 4-(subst.)phenyl compounds. The determination of antiproliferative properties of the newly synthesized $13 \alpha-$ estrone derivatives against a panel of five human adherent gynecological cancer cell lines (MCF-7, MDA-MB-231, Hela, SiHa, A2780) was also performed.

\section{Experimental}

\subsection{Chemistry}

Melting points (Mp) were determined with a Kofler hot-stage apparatus and are uncorrected. Elemental analyses were performed with a Perkin-Elmer CHN analyzer model 2400. Thin-layer chromatography: silica gel 60 F254; layer thickness $0.2 \mathrm{~mm}$ (Merck); eluents (ss): 30\% ethyl acetate $/ 70 \%$ hexane, detection with $\mathrm{I}_{2}$ or $\mathrm{UV}(365 \mathrm{~nm})$ after spraying with $5 \%$ phosphomolybdic acid in 50\% aqueous phosphoric acid and heating at $100-120{ }^{\circ} \mathrm{C}$ for $10 \mathrm{~min}$. Flash chromatography: silica gel 60, 40-63 $\mu \mathrm{m}$ (Merck). Reactions under microwave irradiation were 
carried out with a CEM Corporation focused microwave system, Model Discover SP. The maximum power of irradiation was $200 \mathrm{~W}$. $1 \mathrm{H}$ NMR spectra were recorded in DMSO- $\mathrm{d}_{6}$, $\mathrm{CDCl}_{3}$ solution with a Bruker DRX-500 instrument at $500 \mathrm{MHz}$, with $\mathrm{Me}_{4} \mathrm{Si}$ as internal standard. ${ }^{13} \mathrm{C}$ NMR spectra were recorded with the same instrument at $125 \mathrm{MHz}$ under the same conditions. Mass spectrometry: full scan mass spectra of the compounds were acquired in the range of 50 to $1000 \mathrm{~m} / \mathrm{z}$ with a Finnigan TSQ-7000 triple quadrupole mass spectrometer (Finnigan-MAT, San Jose, CA) equipped with a Finnigan electrospray ionization source. Analyses were performed in positive ion mode using flow injection mass spectrometry with a mobile phase of $50 \%$ aqueous acetonitrile containing $0.1 \mathrm{v} / \mathrm{v} \%$ formic acid. The flow rate was $0.3 \mathrm{ml} / \mathrm{min}$. Five $\mu \mathrm{l}$ aliquot of the samples were loaded into the flow. The ESI capillary was adjusted to $4.5 \mathrm{kV}$ and $\mathrm{N}_{2}$ was used as a nebulizer gas.

\subsubsection{Reaction conditions for Suzuki-Miyaura coupling in 3-OH series}

2-Bromo-3-hydroxy-13 $\alpha$-estra-1,3,5(10)-trien-17-one (3a, $175 \mathrm{mg}, 0.50 \mathrm{mmol}$ ) or 4-bromo-3hydroxy-13 $\alpha$-estra-1,3,5(10)-trien-17-one (6a, $175 \mathrm{mg}, 0.50 \mathrm{mmol}), \mathrm{Pd}\left(\mathrm{PPh}_{3}\right)_{4}(58 \mathrm{mg}, 0.050$ mmol, 0.1 equiv), $\mathrm{K}_{2} \mathrm{CO}_{3}$ (276 mg, $2.0 \mathrm{mmol}, 4$ equiv.), (4-subst.)phenylboronic acid (2 equiv.) and toluene $(4 \mathrm{ml})$ were added under nitrogen atmosphere, in $10 \mathrm{~mL}$ Pyrex pressure vessels (CEM, Part \#: 908035) with silicone cap (CEM, Part \#: 909210) and the mixture was heated in a CEM microwave reactor at $100{ }^{\circ} \mathrm{C}$ for 30 min under stirring. The solvent was evaporated in vacuo. The residue was purified by flash chromatography with $10 \%$ ethyl acetate/ $90 \%$ hexane as eluent.

2.1.1.1. 3-Hydroxy-2-phenyl-13 $\alpha$-estra-1,3,5(10)-trien-17-one (11a)

Compound 11a was isolated as white crystals (165 mg, 95\%). Mp.: 197-205 ${ }^{\circ} \mathrm{C} . \mathrm{R}_{\mathrm{f}}=0.46$. Anal calcd. for $\mathrm{C}_{24} \mathrm{H}_{26} \mathrm{O}_{2}$ : C, 83.20; H, 7.56. Found: 83.28; H, 7.61. ${ }^{1} \mathrm{H}$ NMR (DMSO-d 6 ) $\delta$ ppm: 0.96 (s, 3H, H-18), 2.72 (m, 2H, H-6), 6.59 (s, 1H, H-4), 7.08 (s, 1H, H-1), 7.25 (t, J=7.5 Hz, 1H, H-4'), 7.34 (t, J=7.5 Hz, 2H, H-3' and H-5'), 7.49 (d, J=7.1 Hz, 2H, H-2' and H-6'), 9.17 (s, 1H, 3-OH). ${ }^{13} \mathrm{C}$ NMR (DMSO-d $) \delta$ ppm: $20.4\left(\mathrm{CH}_{2}\right), 24.5(\mathrm{C}-18), 27.7\left(\mathrm{CH}_{2}\right), 28.0$ $\left(\mathrm{CH}_{2}\right), 29.2\left(\mathrm{CH}_{2}\right), 31.6\left(\mathrm{CH}_{2}\right), 32.8\left(\mathrm{CH}_{2}\right), 40.6(\mathrm{CH}), 40.8(\mathrm{CH}), 48.5(\mathrm{CH}), 49.4(\mathrm{C}-13), 115.4$ (C-4), 125.2 (C-2), 126.1 (C-4'), 127.6 (C-1), 127.7 (2C, 2×CH), 128.9 (2C, 2×CH), $130.3(\mathrm{C})$, 136.8 (C), $138.8(\mathrm{C}), 151.8$ (C-3), 220.6 (C-17). MSI m/z (\%): 345 (100, [M-H]'). 
Compound 12a was isolated as white crystals (180 mg, 94\%). Mp.: $256-257^{\circ} \mathrm{C} . \mathrm{R}_{\mathrm{f}}=0.43$. Anal calcd. for $\mathrm{C}_{24} \mathrm{H}_{25} \mathrm{ClO}_{2}$ : C, 75.68; H, 6.62. Found: 75.75; H, 6.53. ${ }^{1} \mathrm{H}$ NMR (DMSO-d 6 ) $\delta$ ppm: 0.97 (s, 3H, H-18), 2.72 (m, 2H, H-6), 6.60 (s, 1H, H-4), 7.10 (s, 1H, H-1), 7.40 (d, J=8.6 Hz, 2H, H-3' and H-5'), 7.52 (d, $J=8.6 \mathrm{~Hz}, 2 \mathrm{H}, \mathrm{H}-2$ ' and H-6'), 9.31 (s, 1H, 3-OH). ${ }^{13} \mathrm{C}$ NMR (DMSO-d $)$ d ppm: $20.4\left(\mathrm{CH}_{2}\right), 24.5(\mathrm{C}-18), 27.7\left(\mathrm{CH}_{2}\right), 28.0\left(\mathrm{CH}_{2}\right), 29.2\left(\mathrm{CH}_{2}\right), 31.5\left(\mathrm{CH}_{2}\right)$, $32.8\left(\mathrm{CH}_{2}\right), 40.6(\mathrm{CH}), 40.8(\mathrm{CH}), 48.5(\mathrm{CH}), 49.4(\mathrm{C}-13), 115.5(\mathrm{C}-4), 123.8(\mathrm{C}-2), 127.4(\mathrm{C}-$ 1), $127.7(2 \mathrm{C}, 2 \times \mathrm{CH}), 130.5(\mathrm{C}), 130.6(2 \mathrm{C}, 2 \times \mathrm{CH}), 130.7$ (C), 137.3(C), $137.6(\mathrm{C}), 151.8(\mathrm{C}-$ 3), 220.6 (C-17). MSI m/z (\%): 379 (100, [M-H] $\left.]^{-}\right)$.

\subsubsection{2-(4-tert-Butylphenyl)-3-hydroxy-13 $\alpha$-estra-1,3,5(10)-trien-17-one (13a)}

Compound 13a was isolated as white crystals (187 mg, 93\%). Mp.: $238-240{ }^{\circ} \mathrm{C} . \mathrm{R}_{\mathrm{f}}=0.54$. Anal calcd. for $\mathrm{C}_{28} \mathrm{H}_{34} \mathrm{O}_{2}$ : C, 83.54; $\mathrm{H}, 8.51$. Found: 83.61; H, 8.42. ${ }^{1} \mathrm{H}$ NMR (DMSO-d $\left.{ }_{6}\right) \delta$ ppm: 0.96 (s, 3H, H-18), 1.29 (s, 9H, 4'-C( $\left.\left.\underline{\mathrm{C}}_{3}\right)_{3}\right), 2.71$ (m, 2H, H-6), 6.58 (s, 1H, H-4), 7.07 (s, 1H, H-1), 7.25 (t, J=7.5 Hz, 1H, H-4'), 7.40 (2xd, J=8.5 Hz, 2x2H, H-2',H-3', H-5' and H-6'), 9.14 (s, 1H, 3-OH). ${ }^{13} \mathrm{C}$ NMR (DMSO-d $) \delta$ ppm: $20.4\left(\mathrm{CH}_{2}\right), 24.5(\mathrm{C}-18), 27.7\left(\mathrm{CH}_{2}\right), 28.0\left(\mathrm{CH}_{2}\right)$, $29.2\left(\mathrm{CH}_{2}\right), 31.0\left(3 \mathrm{C}, 4^{\prime}-\mathrm{C}\left(\underline{\mathrm{CH}}_{3}\right)_{3}\right), 31.6\left(\mathrm{CH}_{2}\right), 32.8\left(\mathrm{CH}_{2}\right), 34.0\left(4^{\prime}-\underline{\mathrm{C}}\left(\mathrm{CH}_{3}\right)_{3}, 40.6(\mathrm{CH}), 40.8\right.$ $(\mathrm{CH}), 48.5(\mathrm{CH}), 49.4(\mathrm{C}-13), 115.4(\mathrm{C}-4), 124.5(2 \mathrm{C}, 2 \times \mathrm{CH}), 125.1(\mathrm{C}-2), 127.6(\mathrm{C}-1), 128.6$ (2C, $2 \times \mathrm{CH}), 130.3(\mathrm{C}), 135.9$ (C), 136.5 (C), 148.3 (C), 151.8 (C-3), 220.6 (C-17). MSI m/z (\%): $401\left(100,[\mathrm{M}-\mathrm{H}]^{-}\right)$.

\subsubsection{3-Hydroxy-4-phenyl-13 $\alpha$-estra-1,3,5(10)-trien-17-one (14a)}

Compound 14a was isolated as white crystals (163 mg, 94\%). Mp.: $125-129{ }^{\circ} \mathrm{C}$. $\mathrm{R}_{\mathrm{f}}=0.56$. Anal calcd. for $\mathrm{C}_{24} \mathrm{H}_{26} \mathrm{O}_{2}$ : C, 83.20; H, 7.56. Found: 83.29; H, 7.50. ${ }^{1} \mathrm{H}$ NMR (DMSO-d 6 ) $\delta$ ppm: 0.96 (s, 3H, H-18), 6.71 (d, J= 8.5 Hz, 1H, H-2), 7.08 (d, J=8.5 Hz, 1H, H-1), 7.13 (t, J=7.4 Hz, 2H, H-3' and H-5'), 7.27 (t, J=7.4 Hz, 1H, H-4'), 7.36 (overlapping multiplets, 2H, H-2' and H-6'), 8.82 (s, 1H, 3-OH). ${ }^{13} \mathrm{C}$ NMR (DMSO-d 6$) \delta$ ppm: $20.9\left(\mathrm{CH}_{2}\right), 24.9(\mathrm{C}-18), 28.3$ $\left(\mathrm{CH}_{2}\right), 28.7\left(\mathrm{CH}_{2}\right), 29.3\left(\mathrm{CH}_{2}\right), 32.2\left(\mathrm{CH}_{2}\right), 33.3\left(\mathrm{CH}_{2}\right), 40.8(\mathrm{CH}), 41.6(\mathrm{CH}), 49.0(\mathrm{CH}), 49.9$ (C-13), $112.8(\mathrm{C}-2), 125.4(\mathrm{CH}), 126.2(\mathrm{CH}), 127.6(\mathrm{C}), 127.8(2 \mathrm{C}, 2 \times \mathrm{CH}), 129.9(2 \mathrm{C}, 2 \times \mathrm{CH})$, 130.2 (C), 135.5 (C), 137.9 (C), 152.0 (C-3), 220.6 (C-17). MSI m/z (\%): 345 (100, [M-H]-). 
Compound 12a was isolated as white crystals (175 mg, 92\%). Mp.: $71-78^{\circ} \mathrm{C}$. $\mathrm{R}_{\mathrm{f}}=0.59$. Anal calcd. for $\mathrm{C}_{24} \mathrm{H}_{25} \mathrm{ClO}_{2}$ : C, 75.68; H, 6.62. Found: 75.74; H, 6.56. ${ }^{1} \mathrm{H}$ NMR (DMSO-d 6 ) $\delta$ ppm: 0.96 (s, 3H, H-18), 6.71 (d, J=8.5 Hz, 1H, H-2), 7.08 (d, J=8.5 Hz, 1H, H-1), 7.10 (d, J=8.5 Hz, 1H, H-1), 7.13 (m, 2H, H-3' and H-5'), 7.41 (m, 2H, H-2' and H-6'), 8.94 (s, 1H, 3-OH). ${ }^{13} \mathrm{C}$ NMR (DMSO-d $) \delta$ ppm: $20.3\left(\mathrm{CH}_{2}\right), 24.4(\mathrm{C}-18), 27.7\left(\mathrm{CH}_{2}\right), 28.2\left(\mathrm{CH}_{2}\right), 28.7\left(\mathrm{CH}_{2}\right)$, 31.6 $\left(\mathrm{CH}_{2}\right), 32.8\left(\mathrm{CH}_{2}\right), 40.2(\mathrm{CH}), 41.0(\mathrm{CH}), 48.4(\mathrm{CH}), 49.3(\mathrm{C}-13), 112.8(\mathrm{C}-2), 125.8(\mathrm{CH})$, $126.3(\mathrm{C}), 127.8(2 \mathrm{C}, 2 \times \mathrm{CH}), 130.2(\mathrm{C}), 131.0(\mathrm{C}), 131.8(\mathrm{CH}), 131.9(\mathrm{CH}), 135.4(\mathrm{C}), 136.7$ (C), $152.0(\mathrm{C}-3), 220.6(\mathrm{C}-17)$. MSI $m / z(\%): 381\left(100,[\mathrm{M}+\mathrm{H}]^{+}\right)$.

\subsubsection{4-(4-tert-Butylphenyl)-3-hydroxy-13 $\alpha$-estra-1,3,5(10)-trien-17-one (16a)}

Compound 13a was isolated as white crystals (183 mg, 91\%). Mp.: $211-219^{\circ} \mathrm{C} . \mathrm{R}_{\mathrm{f}}=0.72$. Anal calcd. for $\mathrm{C}_{28} \mathrm{H}_{34} \mathrm{O}_{2}$ : C, 83.54; H, 8.51. Found: 83.60; H, 8.42. ${ }^{1} \mathrm{H}$ NMR (DMSO-d 6 ) $\delta$ ppm: 0.96 (s, 3H, H-18), 1.31 (s, 9H, 4'-C(C $\left.\left.\underline{\mathrm{C}}_{3}\right)_{3}\right), 6.69$ (d, J= $\left.8.5 \mathrm{~Hz}, 1 \mathrm{H}, \mathrm{H}-2\right), 7.05$ (m, 3H), 7.37 $(\mathrm{m}, 2 \mathrm{H}), 8.80$ (s, 1H, 3-OH). ${ }^{13} \mathrm{C}$ NMR (DMSO-d 6$) \delta$ ppm: $20.9\left(\mathrm{CH}_{2}\right), 24.9(\mathrm{C}-18), 28.3\left(\mathrm{CH}_{2}\right)$, $28.8\left(\mathrm{CH}_{2}\right), 29.3\left(\mathrm{CH}_{2}\right), 31.7\left(3 \mathrm{C}, 4^{\prime}-\mathrm{C}\left(\underline{\mathrm{CH}}_{3}\right)_{3}\right), 32.2\left(\mathrm{CH}_{2}\right), 33.3\left(\mathrm{CH}_{2}\right), 34.6\left(4{ }^{\prime}-\underline{\mathrm{C}}\left(\mathrm{CH}_{3}\right)_{3}, 40.9\right.$ $(\mathrm{CH}), 41.6(\mathrm{CH}), 49.0(\mathrm{CH}), 49.9(\mathrm{C}-13), 113,3(\mathrm{C}-2), 125.1(2 \mathrm{C}, 2 \times \mathrm{CH}), 125.8(\mathrm{C}-1), 128.0$ (C), $130.1(2 \mathrm{C}, 2 \times \mathrm{CH}), 130.7$ (C), 135.4 (C), 136.3 (C), 148.7 (C), 152.7(C-3), 221.2 (C-17). MSI $m / z(\%): 403\left(100,[\mathrm{M}+\mathrm{H}]^{+}\right)$.

\subsubsection{Reaction conditions for Suzuki-Miyaura coupling in 3-OBn series}

3-Benzyloxy-2-bromo-13 $\alpha$-estra-1,3,5(10)-trien-17-one (3b, $220 \mathrm{mg}, 0.50 \mathrm{mmol})$ or 3Benzyloxy-2-bromo-13 $\alpha$-estra-1,3,5(10)-trien-17-one (6b, $220 \mathrm{mg}, 0.50 \mathrm{mmol}), \mathrm{Pd}\left(\mathrm{PPh}_{3}\right)_{4}(58$ $\mathrm{mg}, 0.050 \mathrm{mmol}, 0.1$ equiv), $\mathrm{K}_{2} \mathrm{CO}_{3}$ (276 mg, $2.0 \mathrm{mmol}$, 4 equiv.), (4-subst.)phenylboronic acid (2 equiv.) and toluene $(4 \mathrm{ml})$ were added under nitrogen atmosphere, in $10 \mathrm{~mL}$ Pyrex pressure vessels (CEM, Part \#: 908035) with silicone cap (CEM, Part \#: 909210) and the mixture was heated in a CEM microwave reactor at $150{ }^{\circ} \mathrm{C}$ for $30 \mathrm{~min}$ under stirring. The solvent was evaporated in vacuo. The residue was purified by flash chromatography with $5 \%$ ethyl acetate/ 95\% hexane as eluent.

\subsubsection{3-Benzyloxy-2-phenyl-13 $\alpha$-estra-1,3,5(10)-trien-17-one (11b)}

Compound 11b was isolated as white crystals (203 mg, 92\%). Mp170-176 ${ }^{\circ} \mathrm{C} . \mathrm{R}_{\mathrm{f}}=0.70$. Anal calcd. for $\mathrm{C}_{31} \mathrm{H}_{32} \mathrm{O}_{2}$ : C, 85.28; H, 7.39. Found: 85.36; H, 7.30. ${ }^{1} \mathrm{H}$ NMR $\left(\mathrm{C}_{6} \mathrm{D}_{6}\right) \delta$ ppm: 0.79 (s, $3 \mathrm{H}, \mathrm{H}-18$ ), 2.55-2.66 (overlapping multiplets, $2 \mathrm{H}, \mathrm{H}-6), 4.79$ (s, 2H, 3-OCH$), 6.63(\mathrm{~s}, 1 \mathrm{H}, \mathrm{H}-$ 4), 7.01-7.32 (overlapping multiplets, $9 \mathrm{H}), 7.21(\mathrm{~d}, J=7.4 \mathrm{~Hz}, 2 \mathrm{H}),{ }^{13} \mathrm{C} \mathrm{NMR}\left(\mathrm{CDCl}_{3}\right) \delta \mathrm{ppm}$ : $21.1\left(\mathrm{CH}_{2}\right), 25.2(\mathrm{C}-18), 28.3\left(\mathrm{CH}_{2}\right), 28.4\left(\mathrm{CH}_{2}\right), 30.3\left(\mathrm{CH}_{2}\right), 32.1\left(\mathrm{CH}_{2}\right), 33.5\left(\mathrm{CH}_{2}\right), 41.5$ 
(CH), $41.6(\mathrm{CH}), 49.4(\mathrm{CH}), 50.1(\mathrm{C}-13), 70.7\left(\mathrm{OCH}_{2}\right), 113.6(\mathrm{C}-4), 126.7(\mathrm{CH}), 126.9(2 \times \mathrm{CH})$, $127.5(\mathrm{CH}), 127.9(2 \times \mathrm{CH}), 128.4(2 \times \mathrm{CH}), 128.7(\mathrm{CH}), 129.2(2 \times \mathrm{CH}), 129.6(\mathrm{C}), 132.6(\mathrm{C})$, $137.2(\mathrm{C}), 137.5$ (C), 138.8 (C), 153.7 (C), 221.4 (C-17). MSI m/z (\%): $437\left(100,[\mathrm{M}+\mathrm{H}]^{+}\right)$.

\subsubsection{3-Benzyloxy-2-(4-chlorophenyl)-13 $\alpha$-estra-1,3,5(10)-trien-17-one (12b)}

Compound 12b was isolated as white crystals (221 mg, 94\%). Mp.: $149-157^{\circ} \mathrm{C} . \mathrm{R}_{\mathrm{f}}=0.67$. Anal calcd. for $\mathrm{C}_{31} \mathrm{H}_{31} \mathrm{ClO}_{2}$ : C, 79.05; $\mathrm{H}, 6.63$. Found: 79.12; $\mathrm{H}, 6.54 .{ }^{1} \mathrm{H} \mathrm{NMR}\left(\mathrm{CDCl}_{3}\right) \delta \mathrm{ppm:} 1.06$ (s, 3H, H-18), 2.86 (m, 2H, H-6), 5.02 (s, 2H, 3-OCH $), 6.74$ (s, 1H, H-4), 7.21 (s, 1H, H1),7.28-7.34 (overlapping multiplets, $7 \mathrm{H}), 7.47(\mathrm{~m}, 2 \mathrm{H}) .{ }^{13} \mathrm{C} \mathrm{NMR}\left(\mathrm{CDCl}_{3}\right) \delta \mathrm{ppm}: 21.0\left(\mathrm{CH}_{2}\right)$, $25.1(\mathrm{C}-18), 28.2\left(\mathrm{CH}_{2}\right), 28.3\left(\mathrm{CH}_{2}\right), 30.3\left(\mathrm{CH}_{2}\right), 32.0\left(\mathrm{CH}_{2}\right), 33.4\left(\mathrm{CH}_{2}\right), 41.4(\mathrm{CH}), 41.5(\mathrm{CH})$, $49.2(\mathrm{CH}), 50.1(\mathrm{C}-13), 70.5\left(3-\mathrm{OCH}_{2}\right), 113.3(\mathrm{C}-4), 126.8(2 \mathrm{C}, 2 \times \mathrm{CH}), 127.6(\mathrm{C}-2), 127.7$ $(\mathrm{CH}), 128.0(2 \mathrm{C}, 2 \times \mathrm{CH}), 128.4(3 \mathrm{C}, 3 \times \mathrm{CH}), 130.8(2 \mathrm{C}, 2 \times \mathrm{CH}), 132.5(2 \mathrm{C}, 2 \times \mathrm{C}), 137.1(2 \mathrm{C}$, C), $137.6(\mathrm{C}), 153.4(\mathrm{C}-3), 221.5(\mathrm{C}-17)$. MSI $m / z(\%): 472\left(100,[\mathrm{M}+\mathrm{H}]^{+}\right)$.

\subsubsection{3-Benzyloxy-2-(4-tert-butylphenyl)-13a-estra-1,3,5(10)-trien-17-one (13b)}

Compound 13b was isolated as white crystals (227 mg, 92\%). Mp.: 163-166 ${ }^{\circ} \mathrm{C} . \mathrm{R}_{\mathrm{f}}=0$. Anal calcd. for $\mathrm{C}_{35} \mathrm{H}_{40} \mathrm{O}_{2}$ : C, 85.32; H, 8.18. Found: 85.40; H, 8.09. ${ }^{1} \mathrm{H}$ NMR $\left(\mathrm{C}_{6} \mathrm{D}_{6}\right) \delta$ ppm: 0.79 (s, 3H, H-18), 1.27 (s, 9H, 4'-C( $\left.\left.\mathrm{C}_{3}\right)_{3}\right), 2.63$ (m, 2H, H-6), 4.82 (s, 2H, 3-OCH $)_{2}, 6.66$ (s, 1H, H4), 7.03 (t, $J=7.3 \mathrm{~Hz}, 1 \mathrm{H}, \mathrm{H}-4$ "), 7.11 (t, $J=7.6 \mathrm{~Hz}, 2 \mathrm{H}, \mathrm{H}-3$ ” and H-5”), 7.23 (d, J= $7.5 \mathrm{~Hz}$, 2H, H-2" and H-6"), 7.35(s, 1H, H-1), 7.41 (d, J=8.4 Hz, 2H), 7.73 (d, J=8.4 Hz, 2H). ${ }^{13} \mathrm{C}$ NMR $\left(\mathrm{CDCl}_{3}\right) \delta$ ppm: $21.0\left(\mathrm{CH}_{2}\right), 25.1(\mathrm{C}-18), 28.2\left(\mathrm{CH}_{2}\right), 28.3\left(\mathrm{CH}_{2}\right), 30.2\left(\mathrm{CH}_{2}\right), 31.4(3 \mathrm{C}$, 4'-C( $\left.\left.\underline{\mathrm{CH}}_{3}\right)_{3}\right), 32.1\left(\mathrm{CH}_{2}\right), 33.4\left(\mathrm{CH}_{2}\right), 34.5\left(4{ }^{\prime}-\underline{\mathrm{C}}\left(\mathrm{CH}_{3}\right)_{3}\right), 41.5(2 \mathrm{C}, 2 \times \mathrm{CH}), 49.2(\mathrm{CH}), 50.1(\mathrm{C}-$ 13), $70.6\left(3-\mathrm{OCH}_{2}\right), 113.5(\mathrm{C}-4), 124.8(2 \mathrm{C}, 2 \times \mathrm{CH}), 126.8(2 \mathrm{C}, 2 \times \mathrm{CH}), 127.4(\mathrm{CH}), 128.3(2 \mathrm{C}$, $2 \times \mathrm{CH}), 128.6(\mathrm{CH}), 128.9(\mathrm{C}), 129.2(2 \mathrm{C}, 2 \times \mathrm{CH}), 132.4(\mathrm{C}), 135.6(\mathrm{C}), 136.8(\mathrm{C}), 137.5(\mathrm{C})$, 149.4 (C), 153.7 (C-3), $221.6(\mathrm{C}-17)$. MSI $m / z(\%): 493\left(100,[\mathrm{M}+\mathrm{H}]^{+}\right)$.

\subsubsection{3-Benzyloxy-4-phenyl-13 $\alpha$-estra-1,3,5(10)-trien-17-one (14b)}

Compound 14b was isolated as white crystals (196 mg, 90\%). Mp.: $58-60{ }^{\circ} \mathrm{C}$. $\mathrm{R}_{\mathrm{f}}=0.72$. Anal calcd. for $\mathrm{C}_{31} \mathrm{H}_{32} \mathrm{O}_{2}$ : C, 85.28; $\mathrm{H}, 7.39$. Found: 85.35; $\mathrm{H}, 7.31 .{ }^{1} \mathrm{H}^{\mathrm{NMR}}\left(\mathrm{CDCl}_{3}\right) \delta \mathrm{ppm:} 1.05$ (s, 3H, H-18), 4.95 (d, J=3.9 Hz, 2H, 3-OCH $), 6.85$ (d, J=8.7 Hz, 1H, H-2), 7.08 (s, 1H, H1), $7.11(\mathrm{~m}, 2 \mathrm{H}), 7.19-7.25$ (overlapping multiplets, $6 \mathrm{H}), 7.33(\mathrm{~m}, 1 \mathrm{H}), 7.41(\mathrm{~m}, 1 \mathrm{H}) .{ }^{13} \mathrm{C} \mathrm{NMR}$ 
$\left(\mathrm{CDCl}_{3}\right) \delta$ ppm: $21.1\left(\mathrm{CH}_{2}\right), 25.1(\mathrm{C}-18), 28.4\left(\mathrm{CH}_{2}\right), 28.5\left(\mathrm{CH}_{2}\right), 28.9\left(\mathrm{CH}_{2}\right), 32.1\left(\mathrm{CH}_{2}\right), 33.4$ $\left(\mathrm{CH}_{2}\right), 41.0(\mathrm{CH}), 41.8(\mathrm{CH}), 49.5(\mathrm{CH}), 50.1(\mathrm{C}-13), 70.5\left(3-\mathrm{OCH}_{2}\right), 111.1(\mathrm{C}-2), 125.7(\mathrm{CH})$, $126.5(2 \mathrm{C}, \mathrm{CH}), 126.6(\mathrm{CH}), 127.3(\mathrm{CH}), 128.0(2 \mathrm{C}, 2 \times \mathrm{CH}), 128.2(2 \mathrm{C}, 2 \times \mathrm{CH}), 129.9(\mathrm{CH})$, 130.1 (CH), 131.2 (C), 133.1 (C), 136.6 (C), 137.6 (C), 137.8 (C), 153.9 (C-3), 221.4 (C-17). $\operatorname{MSI} m / z(\%): 437\left(100,[\mathrm{M}+\mathrm{H}]^{+}\right)$.

\subsubsection{3-Benzyloxy-4-(4-chlorophenyl)-13 $\alpha$-estra-1,3,5(10)-trien-17-one (15b)}

Compound 15b was isolated as white crystals (224 mg, 95\%). Mp.: 67-69 ${ }^{\circ} \mathrm{C}$. $\mathrm{R}_{\mathrm{f}}=0.74$. Anal calcd. for $\mathrm{C}_{31} \mathrm{H}_{31} \mathrm{ClO}_{2}$ : C, 79.05; $\mathrm{H}, 6.63$. Found: 79.11; $\mathrm{H}, 6.56 .{ }^{1} \mathrm{H} \mathrm{NMR}\left(\mathrm{CDCl}_{3}\right) \delta \mathrm{ppm}: 1.04$ (s, 3H, H-18), 4.96 (d, J= 4.5 Hz, 2H, 3- $\mathrm{OCH}_{2}$ ), 6.83 (d, J= 8.7 Hz, 1H, H-2), 7.12 (m, 3H), 7.11-7.25 (overlapping multiplets, $4 \mathrm{H}), 7.28(\mathrm{~m}, 1 \mathrm{H}), 7.37(\mathrm{~m}, 2 \mathrm{H}) .{ }^{13} \mathrm{C} \mathrm{NMR}\left(\mathrm{CDCl}_{3}\right) \delta \mathrm{ppm}$ : $21.0\left(\mathrm{CH}_{2}\right), 25.0(\mathrm{C}-18), 28.3\left(\mathrm{CH}_{2}\right), 28.4\left(\mathrm{CH}_{2}\right), 29.0\left(\mathrm{CH}_{2}\right), 32.1\left(\mathrm{CH}_{2}\right), 33.4\left(\mathrm{CH}_{2}\right), 40.9$ $(\mathrm{CH}), 41.7(\mathrm{CH}), 49.3(\mathrm{CH}), 50.1(\mathrm{C}-13), 70.2\left(3-\mathrm{OCH}_{2}\right), 110.8(\mathrm{C}-2), 126.1(\mathrm{CH}), 126.5(2 \mathrm{C}$, $2 \times \mathrm{CH}), 127.4(\mathrm{CH}), 128.2(2 \mathrm{C}, 2 \times \mathrm{CH}), 128.3(2 \mathrm{C}, 2 \times \mathrm{CH}), 129.6(\mathrm{C}), 131.3(\mathrm{CH}), 131.5(\mathrm{CH})$, 132.5 (C), 133.0 (C), 136.2 (C), $136.5(\mathrm{C}), 137.4$ (C), 153.7 (C-3), 221.6 (C-17). MSI m/z (\%): $494\left(100,[\mathrm{M}+\mathrm{Na}]^{+}\right)$.

\subsubsection{3-Benzyloxy-4-(4-tert-butylphenyl)-13 $\alpha$-estra-1,3,5(10)-trien-17-one (16b)}

Compound 16b was isolated as white crystals (222 mg, 90\%). Mp.: $66-70^{\circ} \mathrm{C}$. $\mathrm{R}_{\mathrm{f}}=0.76$. Anal calcd. for $\mathrm{C}_{35} \mathrm{H}_{40} \mathrm{O}_{2}$ : C, 85.32; H, 8.18. Found: 85.41; $\mathrm{H}, 8.10 .{ }^{1} \mathrm{H}^{\mathrm{NMR}}\left(\mathrm{CDCl}_{3}\right) \delta \mathrm{ppm:} 1.05$ (s, 3H, H-18), 1.38 (s, 9H, 4'-C( $\left.\left.\underline{\mathrm{CH}}_{3}\right)_{3}\right), 4.93$ (d, J=6.5 Hz, $\left.2 \mathrm{H}, 3-\mathrm{OCH}_{2}\right), 6.85$ (d, J= $8.6 \mathrm{~Hz}$, 1H, H-2), $7.06(\mathrm{~m}, 2 \mathrm{H}), 7.14(\mathrm{~m}, 1 \mathrm{H}), 7.21(\mathrm{~m}, 5 \mathrm{H}), 7.43(\mathrm{~m}, 2 \mathrm{H}) .{ }^{13} \mathrm{C} \mathrm{NMR}\left(\mathrm{CDCl}_{3}\right) \delta \mathrm{ppm}$ : $21.0\left(\mathrm{CH}_{2}\right), 25.0(\mathrm{C}-18), 28.4\left(\mathrm{CH}_{2}\right), 28.5\left(\mathrm{CH}_{2}\right), 29.0\left(\mathrm{CH}_{2}\right), 31.4\left(3 \mathrm{C}, 4{ }^{\prime}-\mathrm{C}\left(\mathrm{CH}_{3}\right)_{3}\right), 32.1$ $\left(\mathrm{CH}_{2}\right), 33.4\left(\mathrm{CH}_{2}\right), 34.5\left(4^{\prime}-\underline{\mathrm{C}}\left(\mathrm{CH}_{3}\right)_{3}\right), 40.9(\mathrm{CH}), 41.8(\mathrm{CH}), 49.4(\mathrm{CH}), 50.1(\mathrm{C}-13), 70.5(3-$ $\left.\mathrm{OCH}_{2}\right), 111.3(\mathrm{C}-2), 124.8(2 \mathrm{C}, 2 \times \mathrm{CH}), 125.5(\mathrm{CH}), 126.5(2 \mathrm{C}, 2 \times \mathrm{CH}), 127.2(\mathrm{CH}), 128.1(3 \mathrm{C}$, $3 \times \mathrm{CH}), 129.4(\mathrm{CH}), 129.6(\mathrm{CH}), 131.3(\mathrm{C}), 134.6(\mathrm{CH}), 136.8(\mathrm{C}), 137.6(\mathrm{C}), 149.3(\mathrm{C}), 154.1$ (C-3), 221.7 (C-17). MSI m/z (\%): $493\left(100,[\mathrm{M}+\mathrm{H}]^{+}\right)$.

\subsection{Determination of antiproliferative activities}

The antiproliferative properties of the newly synthesized compounds (3, 6 and 11-16) were determined on a panel of human adherent cancer cell lines of gynecological origin. MCF-7 and MDA-MB-231 were isolated from breast cancers differing in biochemical background, while A2780 cells were isolated from ovarian cancer. Hela and SiHa are cervical cancer cell lines 
positive for HPV-18 and HPV-16, respectively. The cancer selectivity of compounds was tested on the non-cancerous mouse embryo fibroblast cell line NIH/3T3. All cell lines were purchased from European Collection of Cell Cultures (ECCAC, Salisbury, UK) exception for Siha (American Tissue Culture Collection, Manassas, VA, USA). Cells were cultivated in minimal essential medium supplemented with $10 \%$ fetal bovine serum, $1 \%$ non-essential amino acids and an antibiotic-antimycotic mixture. All media and supplements were obtained from Lonza Group Ltd., Basel, Switzerland. Near-confluent cancer cells were seeded onto a 96-well microplate (5000 cells/well) and, after overnight standing, $200 \mu \mathrm{L}$ new medium, containing the tested compounds at 10 and $30 \mu \mathrm{M}$, was added. After incubation for $72 \mathrm{~h}$ at $37^{\circ} \mathrm{C}$ in humidified air containing $5 \% \mathrm{CO}_{2}$, the living cells were assayed by the addition of $20 \mu \mathrm{L}$ of $5 \mathrm{mg} / \mathrm{ml} \mathrm{3-}$ (4,5-dimethylthiazol-2-yl)-2,5-diphenyltetrazolium bromide (MTT) solution. MTT was converted by intact mitochondrial reductase and precipitated as purple crystals during a 4-h contact period. The medium was next removed and the precipitated formazan crystals were dissolved in $100 \mu \mathrm{L}$ of DMSO during a 60 -min period of shaking at $37^{\circ} \mathrm{C}$.

Finally, the reduced MTT was assayed at $545 \mathrm{~nm}$, using a microplate reader utilizing wells with untreated cells serving as control [31]. In the case of the most active compounds (i.e. higher than $50 \%$ growth inhibition at $30 \mu \mathrm{M}$ ), the assays were repeated with a set of dilutions, sigmoidal dose-response curves were fitted to the determined data and the $\mathrm{IC}_{50}$ values (the concentration at which the extent of cell proliferation was half that of the untreated control) were calculated by means of GraphPad Prism 4.0 (GraphPad Software, San Diego, CA, USA). All in vitro experiments were carried out on two microplates with at least five parallel wells. Stock solutions of the tested substances $(10 \mathrm{mM})$ were prepared in DMSO. The highest DMSO content of the medium $(0.3 \%)$ did not have any substantial effect on cell proliferation. Cisplatin (Ebewe Pharma GmbH, Unterach, Austria) was used as positive control. 


\section{Results and discussion}

The aromatic ring of $13 \alpha$-estrone might readily be halogenated using different types of halogenating agents (Scheme 1, [8]). $\mathrm{N}$-Halosuccinimides are suitable for the non-selective transformations of the phenolic moiety. Due to the activated behavior of ring A, and the orthodirecting ability of the 3-OH group, a mixture of mono (2- or 4-substituted) and bis (2,4disubstituted) derivatives is formed. We demonstrated recently that the chemo- and regioselectivity of halogenations depend on the reagent and solvent applied [8]. Additionally, the nature and the size of the functional group at $\mathrm{C}-3$ also influence the outcome of the reactions. Bis-2,4-derivates (beside the monosubstituted compounds) were formed exclusively when the starting compound possessed a phenolic OH group. In the case of methyl or benzyl ethers, only monosubstitutions occurred. We showed recently that $13 \alpha$-estrone derivatives halogenated at ring A represent a very promising compound class with diverse biological activities. Enzymes 17 $\beta$-hydroxysteroid dehydrogenase 1 (17 $\beta$-HSD1 and steroid sulfatase (STS) involved in estradiol biosynthesis could effectively be inhibited by certain halo derivatives. The 3-hydroxy2,4-bis-iodo derivative proved to be a dual inhibitor. The 2-bromo-3-hydroxy derivative should also be highlighted as it also displayed dual inhibitory properties against 17ß-HSD1 enzyme and OATP2B1 transporter $[8,13]$. These favorable biological properties of compounds halogenated at ring $\mathrm{A}$ inspired us to perform further synthetic transformations using the compounds as aryl halide substrates. First, $\mathrm{C}\left(\mathrm{sp}^{2}\right)-\mathrm{C}(\mathrm{sp})$ couplings were carried out in order to introduce large, but apolar groups onto the C-2 and C-4 positions. Sonogashira couplings with phenylacetylenes in the 3-OH series resulted in new compounds with substantial 17 $\beta$-HSD1 inhibitory potentials [9]. Products in the C-2 series, in turn, exhibited exclusive inhibitory potentials. These results suggest that the nature of the substituents at C-2, C-3 and/or C-4 exerts a great impact on the biological activity of $13 \alpha$-estrone derivatives.

\section{Scheme 1.}

$13 \alpha$-Estrone was diversified at several sites, including different modifications at C-3 and/or in ring $\mathrm{D}$ with the aim of getting new compounds with potential antiproliferative behavior. It was shown that certain derivatives possess substantial cell growth-inhibitory potential against a number of human cancer cell lines of reproductive origin. We proved in many cases, that the presence of the apolar, bulky benzyl ether function at position C-3 is markedly beneficial concerning the antiproliferative potential $[14,15,17]$. 
It follows that 3-OH compounds might have increased enzyme inhibitory properties, whereas 3-OBn derivatives might be promising cytostatic candidates. Nevertheless, it is worth evaluating new compounds in both series in order to get an insight into the correlation between activity and structure.

Based on these findings, we selected $13 \alpha$-estrone and its 3-O-benzyl counterpart as starting materials. The latter was synthesized in one step from estrone 3-benzyl ether in reaction with ortho-phenylenediamine in acetic acid. The Pd/C-catalyzed hydrogenolysis of the 3-benzyl$13 \alpha$-estrone product resulted in $13 \alpha$-estrone in high yield. The halogenation of 3-OH and 3OBn substrates was achieved using $N$-halosuccinimides as described earlier [8]. Three different electrophile triggers (NCS, NBS or NIS) were used for the formation of aryl halides in order to investigate the influence of the nature of the halogen substituent on the $\mathrm{C}-\mathrm{C}$ coupling reaction. The monosubstituted regioisomers $(\mathbf{2 a}, \mathbf{b}-\mathbf{7 a}, \mathbf{b})$ served as starting compounds in SuzukiMiyaura couplings (Scheme 2).

\section{Scheme 2}

Phenylboronic acid and its two 4-substituted derivatives were chosen as coupling partners. 4Chlorophenylboronic acid seemed to be interesting due to the dual (negative inductive but positive mesomeric) electronic properties of chlorine. The large alkyl substituent in 4-tertbutylphenylboronic acid might greatly influence the biological behavior as earlier established [15]. The reaction conditions applied here have been chosen according to our coupling methods described recently. $\mathrm{Pd}\left(\mathrm{PPh}_{3}\right)_{4}$ was used as catalyst, $\mathrm{K}_{2} \mathrm{CO}_{3}$ as base, and transformations have been carried out under microwave irradiation. First we performed $\mathrm{C}-\mathrm{C}$ couplings of substrate $\mathbf{2 a}, \mathbf{b}-7 \mathbf{a}, \mathbf{b}$ with phenylboronic acid as a model reagent (Table 1). 2-Substituted regioisomers in the 3-OH series (3a, 4a) could efficiently be transformed (Table 1, Entries 2 and 3), except for the 2-chloro derivative (2a, Table 1, Entry 1). The latter could only be coupled using $\mathrm{KO} t$ - $\mathrm{Bu}$ as base at elevated temperature $\left(150^{\circ} \mathrm{C}\right)$ and longer microwave irradiation (60 min) (Table 1 , Entry 13). These conditions proved to be applicable for the transformations of 4-chloro-3hydroxy (5a) and 3-benzyloxy-2- or 4-chloro derivatives ( $2 \mathbf{b}$ and $\mathbf{5 b}$ ), too (Table 1, Entries 1416). Concerning the reactions of bromo or iodo compounds $(\mathbf{3}, \mathbf{4}, \mathbf{6}$, and $\mathbf{7})$, these substrates behaved in a similar way in these reactions (irrespective of the regioisomerism) (Table 1, Entries 2, 3, 5, 6, 8, 9, 11, 12). However, pronounced dehalogenation were observed in the case of iodo starting compounds (Table 1, Entries 3, 6, 9, 12). The nature of the substituent at C-3 of $13 \alpha$-estrane core influenced the outcome of couplings as established earlier in Hirao reactions 
[10]. Benzyl ethers needed harsher conditions (higher reaction temperature) than their hydroxy counterparts, due to stronger steric hindrance (Table 1, Entries 8, 9, 11, 12).

Table 1

After establishing the appropriate reaction conditions (Table 1, Entries 2 and 8), 2- or 4-bromo3-OH and -3-OBn derivatives $(\mathbf{3 a}, \mathbf{b}$ or $\mathbf{6 a}, \mathbf{b})$ have been chosen for further transformations (Scheme 3). Suzuki-Miyaura couplings with subst.-phenylboronic acids afforded the desired products (11-16) in excellent yields. 12 new arylated compounds have been synthesized. The structure of the newly synthesized $13 \alpha$-estrone derivatives $(\mathbf{1 1}-\mathbf{1 6})$ have been deduced from ${ }^{1} \mathrm{H}$ and ${ }^{13} \mathrm{C}$ NMR spectra.

Scheme 3

The antiproliferative properties of the phenylated compounds $(\mathbf{1 1 a}, \mathbf{b}-\mathbf{1 6 a}, \mathbf{b})$ and their direct precursors $(\mathbf{3 a}, \mathbf{b}$ and $\mathbf{6 a}, \mathbf{b})$ were determined in vitro on a panel of human adherent breast (MCF7 and MDA-MB-231), cervical (HeLa and SiHa), and ovarian (A2780) cancer cell lines by means of MTT assay (Table 2). The two breast cancer cell lines involved in this study have different receptorial status [32-34]. In contrast with the estrogen receptor positive MCF-7 cell line, MDA-MB-231 is a triple-negative cell line lacking all current clinically utilized pharmacological targets (receptors for estrogens, progesterone, and growth factor HER2/neu) for hormonal treatment. The triple-negative subtype of breast cancer, therefore, represents the portion of poorest prognosis among breast cancer cases [35]. The majority of cervical cancers is associated with human papilloma virus (HPV) infection [36,37]. Despite vaccination and screening, cervical cancer still causes high mortality rate in less developed countries. The utilized cell lines Hela and Siha represent HPV-18 and -16 positive cases, respectively. These two types of HPV are responsible for nearly $70 \%$ of cervical cancerous cases. Ovarian cancer is another common type of gynecological malignancies [38]. Its poor prognosis and high mortality rates arise from its high recurrence and acquired resistance to drug treatment. In order to investigate the antiproliferative properties of the synthesized compounds, the ovarian cancer cell line A2780 was also included. Evaluation of the promising antiproliferative compounds on 
the mentioned cell lines might initiate the development of new anticancer agents acting with better tolerance and higher effectiveness.

Our data reveal conclusive structure-activity correlations concerning the bromo derivatives (3a,b and 6a,b, Table 2). The 3-OH compounds (3a and 6a) did not influence the cell growth of the tested tumor cells markedly. However, the 4-regioisomer $\mathbf{6} \mathbf{b}$ of benzyl ethers exerted outstanding antiproliferative effect against all investigated cell lines. MCF-7 cells were the most sensitive to $\mathbf{6 b}$ with $\mathrm{IC}_{50}$ value in a submicromolar range. Compound $\mathbf{6 b}$ exerted somewhat lower inhibition against the cervical cell lines Hela and $\mathrm{SiHa}$ and triple negative breast cancer MDA-MB-231 with $\mathrm{IC}_{50}$ values in the low micromolar range. It is worth mentioning that $\mathbf{6 b}$ made a marked distinction between the two breast cancer cell lines, but not between the two cervical ones. The other 3-OBn regioisomer (3b) exhibited weak antiproliferative effect on the tested cell lines. As concerns compounds $\mathbf{3 b}$ and $\mathbf{6 b}$, it should be highlighted, that substantial dependence of the regioselectivity on the antiproliferative potential was observed (in favor of the 4-regioisomer). The most relevant compounds were additionally tested against a mouse fibroblast cell line (NIH-3T3) in order to obtain preliminary data concerning the cancer selectivity of the elicited action. Compound $\mathbf{6 b}$ exerted only a limited (less than $50 \%$ inhibition even at $30 \mu \mathrm{M}$ ) action on this cell line, though the cells are highly sensitive to reference agent cisplatin.

A comparison of the data for phenylated 3-OH (11a and 14a) and brominated 3-OH derivatives (3a and 6a) reveals that the presence of the phenyl ring instead of a bromine improved the antiproliferative activities only for the 2-regioisomer. The calculated $\mathrm{IC}_{50}$ values for compound 11a were over 10 micromoles against MCF-7 and Hela, and the effects were weaker on the other cell lines including mouse fibroblasts. 11a proved to be more effective than $\mathbf{1 4 a}$ its 4 counterpart. A moderate activity enhancement was observed in the case of $\mathbf{1 1 b}$, which might be attributed to the presence of the 3-OBn function. Strikingly, the phenylated 4-regioisomer (14b) was less effective than its 2-counterpart (11b), and far less potent than its bromo derivative $\mathbf{6 b}$.

Setting against the results for phenyl and (subst.)phenyl derivatives demonstrates that the nature and the size of the ring A substituents greatly influence cytostatic properties.

In general, compounds 13a and 16a bearing the $4 "-t$-Bu function seemed to be more potent than 11a and 14a. The 3-OBn-4"-t-Bu derivatives (13b and 16b) displayed very weak growth inhibition, irrespective of the substitution pattern of ring A.

Substantial enhancements in cytostatic potential were detected for the 2-(4"-chlorophenyl) 3$\mathrm{OH}$ compound (12a), except for A2780 cell line. 12a exerted pronounced effect on Hela cells 
with a $3.33 \mu \mathrm{M} \mathrm{IC}_{50}$ value, which is comparable with that of the most potent compound $\mathbf{6 b}$. The next lowest $\mathrm{IC}_{50}$ value was obtained on MCF-7 for compound 12a, but it is far behind the corresponding data of $\mathbf{6 b}$. It is important to note that essential differences arose here in the inhibitory values for the breast and cervical cell line pairs. This was not the case against Hela and $\mathrm{SiHa}$ concerning the results of $\mathbf{6 b}$. The activity dependence of regioisomerism here was also significant, but the tendency was reversed to that in the case of $\mathbf{3 b}$ and $\mathbf{6 b}$. Here the 2isomer (12a) was far more potent than its 4-counterpart (15a). The latter does not seem to be true for the (4"-chlorophenyl)-3-OBn compounds (12b and $\mathbf{1 5 b})$, since $\mathbf{1 5 b}$ exerted more pronounced cell growth inhibitory effect against all cell lines. This is in a good agreement with the data obtained for $\mathbf{3 b}$ and $\mathbf{6 b}$, but the potency of $\mathbf{1 5 b}$ is appreciably lower.

Our 2-phenylethynyl derivative (I) synthesized recently was additionally included in the investigations. We were interested in comparison of the antiproliferative properties of 2-phenyl (11a) and 2-phenylethynyl (I) derivatives. The data in Table 2 reflect that the moderate activity of 11a decreased substantially, when a short linear linker $(C \equiv C)$ is inserted between the two phenyl groups. Accordingly, the nature and geometry of the connection might substantially influence the growth-inhibitory properties of the cross-coupled compounds.

Table 2 


\section{Conclusion}

In conclusion, 2- or 4-[(subst.) phenyl]-13 $\alpha$-estrone derivatives have been synthesized via efficient, microwave-induced, Pd-catalyzed Suzuki-Miyaura coupling. Reactions of 2- or 4halogenated $13 \alpha$-estrone derivatives with (4-subst.)phenylboronic acids using $\mathrm{Pd}\left(\mathrm{PPh}_{3}\right)_{4}$ as catalyst afforded the desired phenylated products in high yields. Certain effective submicromolar or low micromolar cell growth inhibitors (6b, 12a, and 13a) have been identified against human cancer cell lines of gynecological origin. The estrogen receptor positive MCF-7 and the HPV-18 positive Hela cancer cell lines were the most sensitive to the tested compounds. None of the most promising agents exerted substantial growth inhibitory action against fibroblasts indicating the cancer selectivity of the action. The most potent compound (6b) exerted outstanding submicromolar antitumoral activity against MCF-7 cell line and lower calculated $\mathrm{IC}_{50}$ values against all cell lines in comparison to those of reference agent cisplatin. The most effective phenylated compound (12a) exerted selective low micromolar activities against two cell lines (MCF-7 and Hela). Compounds $6 \mathbf{b}$ and 12a behaved similarly as concerns breast cell lines MCF-7 and MDA-MB-231. However, 12a differentiated between the two cervical cell lines Hela and SiHa. Accordingly, ring A substitution of $13 \alpha-$ estrone derivatives leads to effective antitumoral compounds. The substitution pattern of the aromatic ring influences cell growth inhibition markedly. The promising inhibitory data motivate further structural modifications in ring A of $13 \alpha$-estrone, and additional investigations on the mechanism of antiproliferative action. 
Acknowledgements: The work of Erzsébet Mernyák in this project was supported by the János Bolyai Research Scholarship of the Hungarian Academy of Sciences. The work of Erzsébet Mernyák in this project was supported by the ÚNKP-19-4-SZTE-71 „NEW NATIONAL EXCELLENCE PROGRAM OF THE MINISTRY OF HUMAN CAPACITIES”. This work was supported by National Research, Development and Innovation Office-NKFIH through project OTKA SNN 124329. Support from Ministry of Human Capacities, Hungary grant 20391-3/2018/FEKUSTRAT is acknowledged. 


\section{References}

[1] S.S. Smith, Female sex steroid hormones: from receptors to networks to performanceactions on the sensorimotor system, Prog. Neurobiol. 44 (1994) 55-86. https://doi.org/10.1016/0301-0082(94)90057-4.

[2] E.J. Solum, J.J. Cheng, I.B. Sørvik, R.E. Paulsen, A. Vik, T.V. Hansen, Synthesis and biological evaluations of new analogs of 2-methoxyestradiol: inhibitors of tubulin and $\begin{array}{llllll}\text { angiogenesis, } & \text { Eur. } & \text { J. } & \text { Med. } & \text { Chem. } & \end{array}$ (2014) https://doi.org/10.1016/j.ejmech.2014.08.002.

[3] A. Gupta, B.S. Kumar, A.S. Negi, Current status on development of steroids as anticancer agents, J. Steroid Biochem. Mol. Biol. 137 (2013) 242-70. doi: 10.1016/j.jsbmb.2013.05.011. [4] B. Schonecker, C. Lange, M. Kotteritzsch, W. Gunther, J. Weston, E. Anders, H. Gorls, Conformational design for 13alpha-steroids, J. Org. Chem. 65 (2000) 5487-5497. https://doi.org/10.1021/jo000108x

[5] K.M. Penov Gasi, D.A. Miljković, L.D. Medić Mijacević, E.A. Djurendić, S.Z. Stojanović, M.N. Sakac, M.Dj. Djurendić, S.M. Stanković, D. Lazar, S. Andrić, R. Kovacević, Synthesis, $\mathrm{X}$-ray crystal structures and biological activity of 16-amino-17-substituted-D-homo steroid derivatives. Steroids. 68 (2003) 667-76. https://doi.org/10.1016/s0039-128x(03)00097-7.

[6] S. Jovanović-Santa, J. Petrović, S. Andrić, R. Kovacević, E. Durendić, M. Sakac, D. Lazar, S. Stanković, Synthesis, structure, and screening of estrogenic and antiestrogenic activity of new 3,17-substituted-16,17-seco-estratriene derivatives, Bioorg. Chem. 31 (2003) 475-84. https://doi.org/10.1016/s0045-2068(03)00101-9.

[7] D. Ayan, J. Roy, R. Maltais, D. Poirier, Impact of estradiol structural modifications (18methyl and/or 17-hydroxy inversion of configuration) on the in vitro and in vivo estrogenic activity, J. Steroid Biochem. Mol. Biol. $127 \quad$ (2011) 324-30. https://doi.org/10.1016/j.jsbmb.2011.07.009.

[8] I. Bacsa, B.E. Herman, R. Jójárt, K.S. Herman, J. Wölfling, G. Schneider, M. Varga, C. Tömböly, T.L. Rižner, M. Szécsi, E. Mernyák, Synthesis and structure-activity relationships of 2- and/or 4-halogenated $13 \beta$ - and $13 \alpha$-estrone derivatives as enzyme inhibitors of estrogen biosynthesis, J. Enzyme. Inhib. Med. Chem. 33 (2018) 1271-1282. https://doi.org/10.1080/14756366.2018.1490731.

[9] I. Bacsa, R. Jójárt, J. Wölfling, G. Schneider, B.E. Herman, M. Szécsi, E. Mernyák, Synthesis of novel $13 \alpha$-estrone derivatives by Sonogashira coupling as potential 17 $\beta$-HSD1 inhibitors, Beilstein J. Org. Chem. 13 (2017) 1303-1309. https://doi.org/10.3762/bjoc.13.126. 
[10] R. Jójárt, S. Pécsy, G. Keglevich, M. Szécsi, R. Rigó, C. Özvegy-Laczka, G. Kecskeméti, E. Mernyák, Pd-Catalyzed microwave-assisted synthesis of phosphonated $13 \alpha$-estrones as potential OATP2B1, 17ß-HSD1 and/or STS inhibitors, Beilstein J. Org. Chem. 14 (2018) 28382845. https://doi.org/10.3762/bjoc.14.262. PMID: 30498534.

[11] G. Möller, D. Deluca, C. Gege, A. Rosinus, D. Kowalik, O. Peters, P. Droescher, W. Elger, J. Adamski, A. Hillisch, Structure-based design, synthesis and in vitro characterization of potent 17beta-hydroxysteroid dehydrogenase type 1 inhibitors based on 2-substitutions of estrone and D-homo-estrone, Bioorg. Med. Chem. Lett. 19 (2009) 6740-4. https://doi.org/10.1016/j.bmcl.2009.09.113.

[12] L.W. Lawrence Woo, B. Leblond, A. Purohit, B.V.L. Potter, Synthesis and evaluation of analogues of estrone-3-O-sulfamate as potent steroid sulfatase inhibitors, Bioorg. Med. Chem. 20 (2012) 2506-19. https://doi.org/10.1016/j.bmc.2012.03.007.

[13] R. Laczkó-Rigó, R. Jójárt, E. Mernyák, É. Bakos, A. Tuerkova, B. Zdrazil, C. ÖzvegyLaczka, Structural dissection of 13-epiestrones based on the interaction with human Organic anion-transporting polypeptide, OATP2B1, J. Steroid Biochem. Mol. Biol. 200 (2020) 105652. https://doi.org/10.1016/j.jsbmb.2020.105652.

[14] E. Mernyák, I. Kovács, R. Minorics, P. Sere, D. Czégány, I. Sinka, J. Wölfling, G. Schneider, Z. Újfaludi, I. Boros, I. Ocsovszki, M. Varga, I. Zupkó, Synthesis of trans-16triazolyl-13 $\alpha$-methyl-17-estradiol diastereomers and the effects of structural modifications on their in vitro antiproliferative activities, J. Steroid Biochem. Mol. Biol. 150 (2015) 123-34. https://doi.org/10.1016/j.jsbmb.2015.04.001.

[15] J. Szabó, Z. Pataki, J. Wölfling, G. Schneide, N. Bózsity, R. Minorics, I. Zupkó, E. Mernyák, Synthesis and biological evaluation of $13 \alpha$-estrone derivatives as potential $\begin{array}{lllll}\text { antiproliferative } & \text { agents, } & \text { Steroids, } & 113 & \text { (2016) }\end{array}$ https://doi.org/10.1016/j.steroids.2016.05.010.

[16] N. Bózsity, R. Minorics, J. Szabó, E. Mernyák, G. Schneider, J. Wölfling, H.C. Wang, C.C. Wu, I. Ocsovszki, I. Zupkó, Mechanism of antiproliferative action of a new d-secoestronetriazole derivative in cervical cancer cells and its effect on cancer cell motility, J. Steroid Biochem. Mol. Biol. 165 (2017) 247-257. https://doi.org/10.1016/j.jsbmb.2016.06.013.

[17] J. Szabó, N. Jerkovics, G. Schneider, J. Wölfling, N. Bózsity, R. Minorics, I. Zupkó, E. Mernyák, Synthesis and in Vitro Antiproliferative Evaluation of C-13 Epimers of Triazolyl-dSecoestrone Alcohols: The First Potent 13 $\alpha$-D-Secoestrone Derivative, Molecules, 21 (2016) 611. https://doi.org/10.3390/molecules21050611. 
[18] E. Mernyák, J. Szabó, I. Bacsa, J. Huber, G. Schneider, R. Minorics, N. Bózsity, I. Zupkó, M. Varga, Z. Bikádi, E, Hazai, J. Wölfling, Syntheses and antiproliferative effects of D-homoand D-secoestrones, Steroids, 87 (2014) 128-36. https://doi.org/10.1016/j.steroids.2014.05.015. [19] E. Mernyák, G. Fiser, J. Szabó, B. Bodnár, G. Schneider, I. Kovács, I. Ocsovszki, I. Zupkó, J. Wölfling, Synthesis and in vitro antiproliferative evaluation of d-secooxime derivatives of

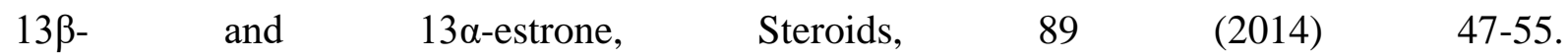
https://doi.org/10.1016/j.steroids.2014.08.015.

[20] A. Kiss, E. Mernyák, J. Wölfling, I. Sinka, I. Zupkó, G. Schneider, Stereoselective synthesis of the four 16-hydroxymethyl-3-methoxy- and 16-hydroxymethyl-3-benzyloxy-13 $\alpha$ estra-1,3,5(10)-trien-17-ol isomers and their antiproliferative activities, Steroids, 134 (2018) 67-77. https://doi.org/10.1016/j.steroids.2018.02.008. Epub 2018 Mar 1. PMID: 29501755.

[21] N. Miyaura and A. Suzuki, Palladium-Catalyzed Cross-Coupling Reactions of Organoboron Compounds, Chem. Rev. $95 \quad$ (1995) 2457-2483. https://doi.org/10.1021/cr00039a007

[22] A.F. Littke, G.C. Fu, Palladium-catalyzed coupling reactions of aryl chlorides, Angew. Chem. Int. Ed. Engl. 41 (2002) 4176-211. https://doi.org/10.1002/15213773(20021115)41:22<4176::AID-ANIE4176>3.0.CO;2-U.

[23] Y. Sato, H. Kamiyama, T. Usui, T. Saito, H. Osada, S. Kuwahara, H. Kiyota, Synthesis and anti-angiogenic activity of cortistatin analogs, Biosci. Biotechnol. Biochem. 72 (2008) 2992-7. https://doi.org/10.1271/bbb.80562.

[24] R. Maltais, D. Poirier, Development of a Gram-Scale Synthesis of PBRM, an Irreversible Inhibitor of 17ß-Hydroxysteroid Dehydrogenase Type 1, Org. Process Res. Dev. 23 (2019), 2323-2335. https://doi.org/10.1021/acs.oprd.8b00402.

[25] A. Ivanov, S.A. Ejaz, S.J.A. Shah, P. Ehlers, A. Villinger, E.Frank, G. Schneider, J. Wölfling, Q. Rahman, J. Iqba, P. Langer, Synthesis, functionalization and biological activity of arylated derivatives of (+)-estrone, Bioorg. Med. Chem. 25 (2017) 949-962. https://doi.org/10.1016/j.bmc.2016.12.009.

[26] S. Jopp, P. Ehlers, E. Frank, E. Mernyák, G. Schneider, J. Wölfling, A. Villinger, P. Langer, Site-Selective Synthesis of 3,17-Diaryl-1,3,5,16-estratetraenes, Synlett, 30 (2019) 600604. https://doi.org/10.1055/s-0037-1611720.

[27] S. Jopp, T. Wallaschkowski, P. Ehlers, E. Frank, G. Schneider, J. Wölfling, E. Mernyak, A. Villinger, P. Langer, Chemoselective Suzuki-Miyaura reactions of 4-bromo-3-O-triflyl- 
estrone. Synthesis and atropisomerism of arylated estrones, Tetrahedron, 74 (2018) 2825-2836. https://doi.org/10.1016/j.tet.2018.02.015.

[28] U. Bothe, M. Busemann, O.M. Fischer, N. Barak, A. Rotgeri, T. Marquardt, C. Stegmann, Methods for the production of 3-substituted estra-1,3,5(10),16-tetraene derivatives and pharmaceutical formulations containing them, PCT Int. Appl. (2014), WO 2014009274 A1 20140116

[29] R. Dutour, J. Roy, F. Cortes-Benitez, R. Maltais, D. Poirier, Targeting Cytochrome P450 (CYP) 1B1 Enzyme with Four Series of A-Ring Substituted Estrane Derivatives: Design, Synthesis, Inhibitory Activity, and Selectivity, J. Med. Chem. 61 (2018) 9229-45. https://doi.org/10.1021/acs.jmedchem.8b00907

[30] C.L. Ciana, R.J. Phipps, J.R. Brandt, F.M. Meyer, M.J. Gaunt, A Highly Para-Selective Copper(II)-Catalyzed Direct Arylation ofAniline and Phenol Derivatives, Angew. Chem. Int. Ed. 50 (2011) 458 -62. https://doi.org/10.1002/anie.201004703

[31] T. Mosmann, Rapid colorimetric assay for cellular growth and survival: application to proliferation and cytotoxicity assays, J. Immunol. Methods. 65 (1983) 55-63. https://doi.org/10.1016/0022-1759(83)90303-4.

[32] Z. Schelz, I. Ocsovszk, N. Bózsity, J. Hohmann, I. Zupkó, Antiproliferative Effects of Various Furanoacridones Isolated from Ruta graveolens on Human Breast Cancer Cell Lines, Anticancer Res. 36 (2016) 2751-8.

[33] K.J. Chavez, S.V. Garimella, S. Lipkowitz, Triple negative breast cancer cell lines: one tool in the search for better treatment of triple negative breast cancer, Breast Dis. 32 (2010) 3548. https://doi.org/10.3233/BD-2010-0307.

[34] C.K. Anders, T.M. Zagar, L.A. Carey, The management of early-stage and metastatic triple-negative breast cancer: a review, Hematol. Oncol. Clin. North. Am. 27 (2013) 737-49. https://doi.org/10.1016/j.hoc.2013.05.003.

[35] Suba Z: Triple-negative breast cancer risk in women is defined by the defect of estrogen signaling: preventive and therapeutic implications. Onco Targets Ther 7: 147-64 (2014) https://doi.org/10.2147/OTT.S52600

[36] A. Goodman, HPV testing as a screen for cervical cancer, BMJ. 30 (2015) 2372. https://doi.org/10.1136/bmj.h2372.

[37] R. Ghittoni, R. Accardi, S. Chiocca, M. Tommasino, Role of human papillomaviruses in $\begin{array}{llll}\text { carcinogenesis, } & \text { Ecancermedicalscience. } & 9 & \text { (2015) }\end{array}$ https://doi.org/10.3332/ecancer.2015.526. 
[38] Y.K. Lee, J. Lim, S.Y. Yoon, J.C. Jo, S.J. Par, Y.J. Park, Promotion of Cell Death in Cisplatin-Resistant Ovarian Cancer Cells through KDM1B-DCLRE1B Modulation, Int. J. Mol. Sci. 20 (2019) 2443. https://doi.org/10.3390/ijms20102443. 


\section{Legends for Tables, Figures and Schemes}

Table 1: Effect of reaction conditions on $\mathrm{C}-\mathrm{C}$ coupling of halogenated $13 \alpha$-estrones $(\mathbf{2 a}, \mathbf{b}-$ 7a,b) with phenylboronic acid in toluene catalyzed by $\mathrm{Pd}\left(\mathrm{PPh}_{3}\right)_{4}{ }^{1}$

Table 2: Antiproliferative properties of the synthesized compounds

Figure 1: The structure of 13a-estrone (1a) and its 3-benzyl ether (1b)

Figure 2: Potent, biologically active $13 \alpha$-estrone derivatives (I, 3a and II)

Scheme 1: Synthesis of ring A halogenated $13 \alpha$-estrone derivatives

Scheme 2: Suzuki-Miyaura couplings with phenylboronic acid as model reagent

Scheme 3: Suzuki-Miyaura couplings of 2- or 4-bromo-13a-estrones. Reactions were performed on a $0.50 \mathrm{mmol}$ scale with 2 equiv of subst.-phenylboronic acid, 0.1 equiv. $\mathrm{Pd}\left(\mathrm{PPh}_{3}\right)_{4}, 4$ equiv. $\mathrm{K}_{2} \mathrm{CO}_{3}$, at $100{ }^{\circ} \mathrm{C}, 30$ min under microwave irradiation. 


\section{Footnotes}

\section{Table 1:}

${ }^{1}$ Aryl halide ( $\left.0.50 \mathrm{mmol}\right), \mathrm{Pd}\left(\mathrm{PPh}_{3}\right)_{4}$ (0.1 equiv), $\mathrm{K}_{2} \mathrm{CO}_{3}$ (4 equiv.), (4-subst.)phenylboronic acid (2 equiv.), toluene, $\mathrm{N}_{2}$ atmosphere.

${ }^{2}$ Flash chromatography yield obtained under microwave irradiation.

Table 2:

${ }^{1}$ Mean value from two independent measurements with five parallel wells; standard deviation $<20 \%$. n.t.: not tested.

${ }^{2}$ Inhibition values $<20 \%$ are not presented 
Table 1.

\begin{tabular}{|c|c|c|c|c|c|}
\hline Entry & Substrate & Base & $\begin{array}{l}\text { Temp } \\
\left({ }^{\circ} \mathrm{C}\right)\end{array}$ & $\begin{array}{l}\text { Reaction } \\
\text { time } \\
\text { (min) }\end{array}$ & $\begin{array}{c}\text { Products }^{2} \\
(\%)\end{array}$ \\
\hline 1 & $2 a$ & $\mathrm{~K}_{2} \mathrm{CO}_{3}$ & 100 & 30 & 0 \\
\hline 2 & $3 \mathbf{a}$ & $\mathrm{K}_{2} \mathrm{CO}_{3}$ & 100 & 30 & $\begin{array}{l}11 \mathbf{a}+1 \mathbf{a} \\
(95+2)\end{array}$ \\
\hline 3 & $4 a$ & $\mathrm{~K}_{2} \mathrm{CO}_{3}$ & 100 & 30 & $\begin{array}{l}\mathbf{1 1 a}+\mathbf{1 a} \\
(83+12)\end{array}$ \\
\hline 4 & $5 a$ & $\mathrm{~K}_{2} \mathrm{CO}_{3}$ & 100 & 30 & 0 \\
\hline 5 & $6 a$ & $\mathrm{~K}_{2} \mathrm{CO}_{3}$ & 100 & 30 & $\begin{array}{l}14 \mathbf{a}+\mathbf{1 a} \\
(94+3)\end{array}$ \\
\hline 6 & $7 a$ & $\mathrm{~K}_{2} \mathrm{CO}_{3}$ & 100 & 30 & $\begin{array}{l}14 a+1 a \\
(80+15)\end{array}$ \\
\hline 7 & $2 b$ & $\mathrm{~K}_{2} \mathrm{CO}_{3}$ & 150 & 30 & 0 \\
\hline 8 & $3 b$ & $\mathrm{~K}_{2} \mathrm{CO}_{3}$ & 150 & 30 & $\begin{array}{c}\mathbf{1 1 b}+\mathbf{1 b} \\
(92+4)\end{array}$ \\
\hline 9 & $4 b$ & $\mathrm{~K}_{2} \mathrm{CO}_{3}$ & 150 & 30 & $\begin{array}{c}\mathbf{1 1 b}+\mathbf{1 b} \\
(82+7)\end{array}$ \\
\hline 10 & $5 \mathbf{b}$ & $\mathrm{K}_{2} \mathrm{CO}_{3}$ & 150 & 30 & 0 \\
\hline 11 & $6 b$ & $\mathrm{~K}_{2} \mathrm{CO}_{3}$ & 150 & 30 & $\begin{array}{c}\mathbf{1 4 b}+\mathbf{1 b} \\
(90+4)\end{array}$ \\
\hline 12 & $7 b$ & $\mathrm{~K}_{2} \mathrm{CO}_{3}$ & 150 & 30 & $\begin{array}{l}\mathbf{1 4 b}+\mathbf{1 b} \\
(81+10)\end{array}$ \\
\hline 13 & $2 a$ & $\mathrm{KO} t-\mathrm{Bu}$ & 150 & 60 & $\begin{array}{l}\text { 11a } \\
(43)\end{array}$ \\
\hline 14 & $5 a$ & $\mathrm{KO} t-\mathrm{Bu}$ & 150 & 60 & $\begin{array}{l}\mathbf{1 4 a} \\
(51)\end{array}$ \\
\hline 15 & $2 b$ & $\mathrm{KO} t-\mathrm{Bu}$ & 150 & 60 & $\begin{array}{l}\mathbf{1 1 b} \\
(41)\end{array}$ \\
\hline 16 & $5 \mathbf{b}$ & $\mathrm{KO} t-\mathrm{Bu}$ & 150 & 60 & $14 \mathrm{~b}$ \\
\hline
\end{tabular}




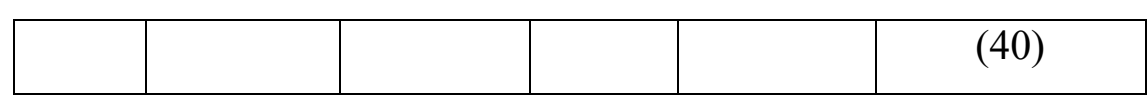


Table 2.

\begin{tabular}{|c|c|c|c|c|c|c|c|c|}
\hline \multirow[t]{2}{*}{ Comp. } & \multirow[t]{2}{*}{$\begin{array}{l}\text { Comp. } \\
\text { number }\end{array}$} & \multirow[t]{2}{*}{$\begin{array}{l}\text { Conc. } \\
(\mu \mathrm{M})\end{array}$} & \multicolumn{6}{|c|}{ 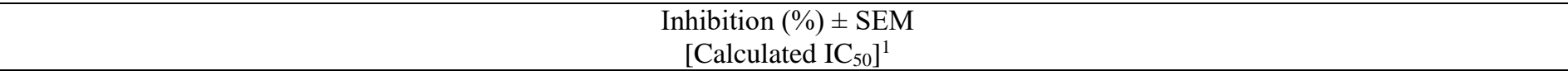 } \\
\hline & & & MCF-7 & MDA-MB-231 & $\mathrm{HeLa}$ & $\mathrm{SiHa}$ & A2780 & NIH-3T3 \\
\hline & \multirow{2}{*}{$3 \mathbf{a}$} & 10 & - & - & - & - & - & \multirow{2}{*}{ n.t. } \\
\hline $\mathrm{HO}^{-}$ & & 30 & $24.26 \pm 0.76$ & $22.85 \pm 1.97$ & $32.26 \pm 0.52$ & $20.72 \pm 3.56$ & - & \\
\hline & \multirow{2}{*}{$6 \mathbf{a}$} & 10 & - & - & - & - & - & \multirow{2}{*}{ n.t. } \\
\hline & & 30 & $51.92 \pm 1.61$ & $42.09 \pm 1.31$ & $54.81 \pm 1.14$ & - & $44.21 \pm 1.09$ & \\
\hline & \multirow{2}{*}{$3 \mathbf{b}$} & 10 & - & - & - & - & - & \multirow{2}{*}{ n.t. } \\
\hline $\mathrm{Bn}$ & & 30 & - & - & $48.57 \pm 1.40$ & - & - & \\
\hline & \multirow{2}{*}{$6 b$} & 10 & $76.67 \pm 0.30$ & $54.41 \pm 0.88$ & $60.23 \pm 0.42$ & $59.04 \pm 1.51$ & $47.78 \pm 2.10$ & $30.59 \pm 0.47$ \\
\hline & & 30 & $\begin{array}{l}79.45 \pm 0.85 \\
\quad(0.52)\end{array}$ & $\begin{array}{l}62.36 \pm 0.67 \\
\quad(3.91)\end{array}$ & $\begin{array}{l}68.16 \pm 0.62 \\
\quad(2.85)\end{array}$ & $\begin{array}{l}63.04 \pm 0.41 \\
\quad(2.74)\end{array}$ & $54.75 \pm 1.06$ & $29.55 \pm 0.36$ \\
\hline & \multirow{2}{*}{$11 \mathrm{a}$} & 10 & $44.72 \pm 0.73$ & $31.50 \pm 1.77$ & $36.82 \pm 0.98$ & $33.49 \pm 0.90$ & $35.73 \pm 1.21$ & $35.48 \pm 1.33$ \\
\hline & & 30 & $\begin{array}{l}71.54 \pm 0.40 \\
\quad(13.12)\end{array}$ & $48.97 \pm 0.42$ & $\begin{array}{l}63.67 \pm 0.30 \\
\quad(17.06)\end{array}$ & $54.36 \pm 0.37$ & $45.89 \pm 0.96$ & $40.04 \pm 1.48$ \\
\hline & \multirow{2}{*}{$14 a$} & 10 & - & - & - & - & - & \multirow{2}{*}{ n.t. } \\
\hline & & 30 & - & - & $27.29 \pm 1.02$ & - & - & \\
\hline & \multirow{2}{*}{$11 b$} & 10 & $32.11 \pm 1.90$ & - & $51.26 \pm 0.20$ & $25.45 \pm 2.09$ & $25.44 \pm 1.06$ & - \\
\hline $\mathrm{BnO}$ & & 30 & $\begin{array}{l}74.50 \pm 1.16 \\
\quad(16.87)\end{array}$ & $\begin{array}{l}76.16 \pm 1.05 \\
\quad(18.92)\end{array}$ & $\begin{array}{l}75.53 \pm 0.18 \\
\quad(8.98)\end{array}$ & $\begin{array}{l}70.06 \pm 1.48 \\
\quad(18.56)\end{array}$ & $\begin{array}{l}73.42 \pm 0.41 \\
\quad(18.62)\end{array}$ & - \\
\hline
\end{tabular}




\begin{tabular}{|c|c|c|c|c|c|c|c|c|}
\hline & & 10 & - & - & - & - & - & \multirow{2}{*}{ n.t. } \\
\hline & & 30 & $27.35 \pm 1.36$ & - & - & - & $27.14 \pm 0.94$ & \\
\hline & \multirow{2}{*}{ 13a } & 10 & $47.97 \pm 0.98$ & $42.24 \pm 1.02$ & $66.29 \pm 0.87$ & $44.03 \pm 1.15$ & $52.46 \pm 0.20$ & $45.30 \pm 2.71$ \\
\hline & & 30 & $\begin{array}{c}66.68 \pm 0.71 \\
(12.82)\end{array}$ & $53.23 \pm 0.35$ & $\begin{array}{c}77.67 \pm 0.42 \\
(6.69)\end{array}$ & $51.95 \pm 0.78$ & $\begin{array}{l}68.13 \pm 0.55 \\
\quad(9.41)\end{array}$ & $51.68 \pm 1.96$ \\
\hline & \multirow{2}{*}{$16 \mathbf{a}$} & 10 & - & - & $38.70 \pm 1.67$ & - & $35.83 \pm 1.92$ & - \\
\hline & & 30 & $\begin{array}{c}96.93 \pm 0.33 \\
(15.73)\end{array}$ & $\begin{array}{c}91.02 \pm 0.59 \\
(17.19)\end{array}$ & $\begin{array}{c}97.96 \pm 0.15 \\
(11.19)\end{array}$ & $\begin{array}{c}92.43 \pm 0.88 \\
(16.90)\end{array}$ & $\begin{array}{c}97.93 \pm 0.17 \\
(10.38)\end{array}$ & - \\
\hline & \multirow{2}{*}{$13 b$} & 10 & - & - & $24.51 \pm 1.62$ & - & - & \multirow{2}{*}{ n.t. } \\
\hline & & 30 & $28.21 \pm 0.85$ & $34.85 \pm 0.52$ & $52.36 \pm 1.25$ & $20.00 \pm 0.79$ & $64.77 \pm 1.82$ & \\
\hline & \multirow{2}{*}{$16 b$} & 10 & - & - & - & - & - & \multirow{2}{*}{ n.t. } \\
\hline$t$-Bu & & 30 & $32.81 \pm 1.33$ & - & - & - & $24.65 \pm 2.81$ & \\
\hline & $12 \mathbf{a}$ & 10 & $53.41 \pm 0.23$ & $25.95 \pm 0.43$ & $73.65 \pm 0.22$ & $50.85 \pm 0.30$ & $24.97 \pm 0.52$ & $26.47 \pm 1.33$ \\
\hline
\end{tabular}




\begin{tabular}{|c|c|c|c|c|c|c|c|c|}
\hline & & 30 & $\begin{array}{c}59.51 \pm 0.22 \\
\quad(5.33)\end{array}$ & $\begin{array}{c}61.92 \pm 0.67 \\
(18.32)\end{array}$ & $\begin{array}{c}75.46 \pm 0.81 \\
(3.33)\end{array}$ & $53.45 \pm 0.95$ & $33.61 \pm 0.74$ & $28.17 \pm 0.25$ \\
\hline & \multirow{2}{*}{$15 a$} & 10 & - & - & - & - & $20.20 \pm 1.13$ & - \\
\hline & & 30 & $\begin{array}{c}88.41 \pm 1.35 \\
(19.76)\end{array}$ & $52.83 \pm 1.31$ & $\begin{array}{c}80.24 \pm 0.21 \\
\quad(17.91)\end{array}$ & $\begin{array}{c}72.66 \pm 1.09 \\
(21.19)\end{array}$ & $\begin{array}{c}82.92 \pm 0.45 \\
(14.97)\end{array}$ & $20.9 \pm 0.42$ \\
\hline & \multirow{2}{*}{$12 b$} & 10 & - & - & - & - & - & \multirow{2}{*}{ n.t. } \\
\hline & & 30 & $36.29 \pm 1.21$ & $22.91 \pm 0.55$ & $56.17 \pm 1.12$ & $47.26 \pm 0.35$ & $34.63 \pm 0.48$ & \\
\hline \multirow{4}{*}{ Cl } & \multirow{2}{*}{$15 b$} & 10 & $48.56 \pm 0.32$ & - & $47.73 \pm 1.65$ & - & - & - \\
\hline & & 30 & $\begin{array}{c}77.13 \pm 0.40 \\
(9.95)\end{array}$ & $33.67 \pm 1.39$ & $64.12 \pm 2.00$ & $62.32 \pm 0.94$ & $55.04 \pm 0.61$ & - \\
\hline & \multirow{2}{*}{ I } & 10 & $23.51 \pm 1.95$ & - & - & - & - & \multirow{2}{*}{ n.t. } \\
\hline & & 30 & $\begin{array}{c}69.00 \pm 0.32 \\
(21.51)\end{array}$ & $29.66 \pm 0.59$ & $59.89 \pm 1.16$ & $46.18 \pm 0.14$ & $\begin{array}{c}78.34 \pm 0.12 \\
(20.82)\end{array}$ & \\
\hline \multirow[t]{2}{*}{ Cisplatin } & & 10 & $53.03 \pm 2.29$ & - & $42.61 \pm 2.33$ & $88.64 \pm 0.50$ & $83.57 \pm 1.21$ & $91.80 \pm 0.39$ \\
\hline & & 30 & $\begin{array}{c}86.90 \pm 1.22 \\
(5.78)\end{array}$ & $\begin{array}{c}71.47 \pm 1.20 \\
(19.13)\end{array}$ & $\begin{array}{c}99.93 \pm 0.26 \\
(12.43)\end{array}$ & $\begin{array}{c}90.18 \pm 1.78 \\
(7.84)\end{array}$ & $\begin{array}{c}95.02 \pm 0.28 \\
(1.30)\end{array}$ & $\begin{array}{c}93.68 \pm 0.20 \\
(2.70)\end{array}$ \\
\hline
\end{tabular}


Figures

Figure 1
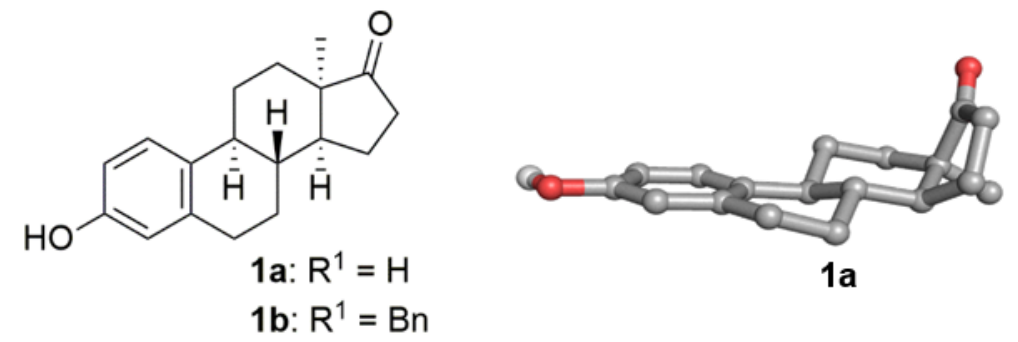

Figure 2

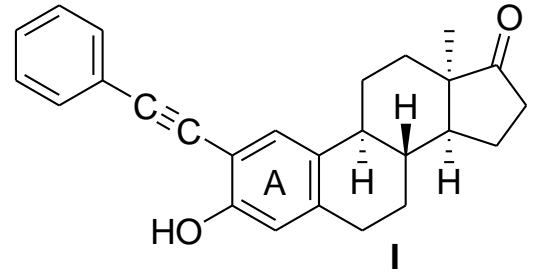

$\mathrm{IC}_{50}=0.15 \mu \mathrm{M}(17 \beta-\mathrm{HSD} 1)$

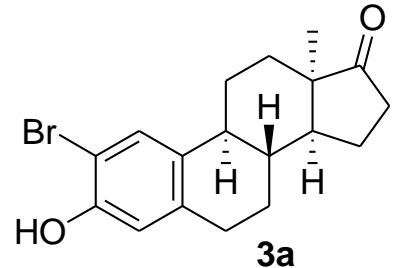

$\mathrm{IC}_{50}=0.54 \mu \mathrm{M}(\mathrm{OATP} 2 \mathrm{~B} 1)$

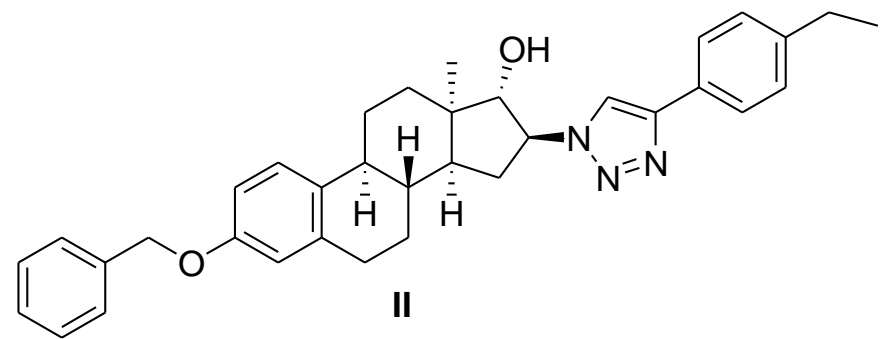

$\mathrm{IC}_{50}=2.4-2.9 \mu \mathrm{M}$ (Hela, A2780, MCF-7) 
Schemes

Scheme 1

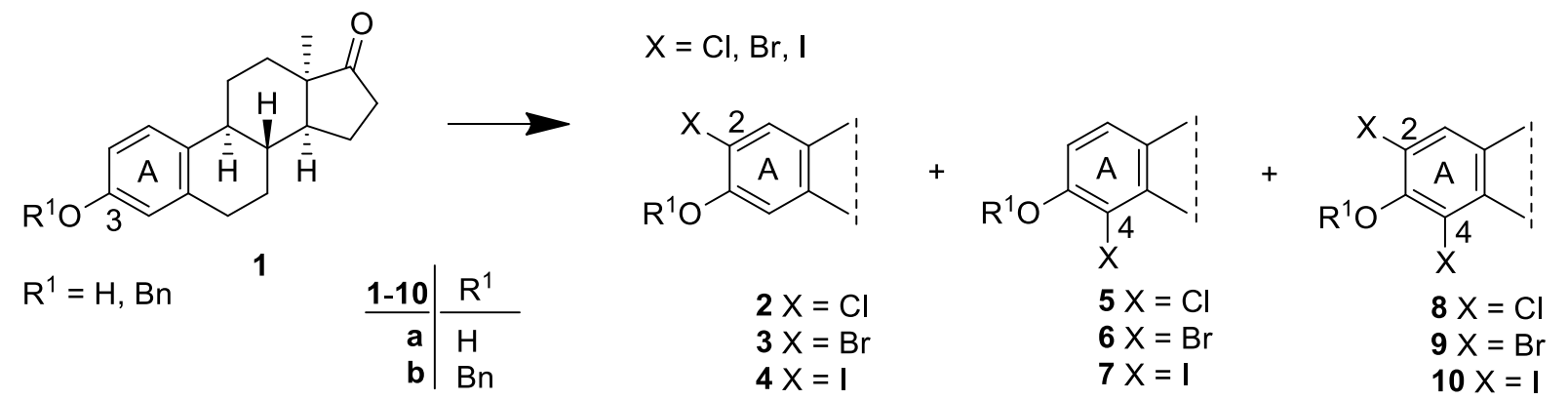

Scheme 2

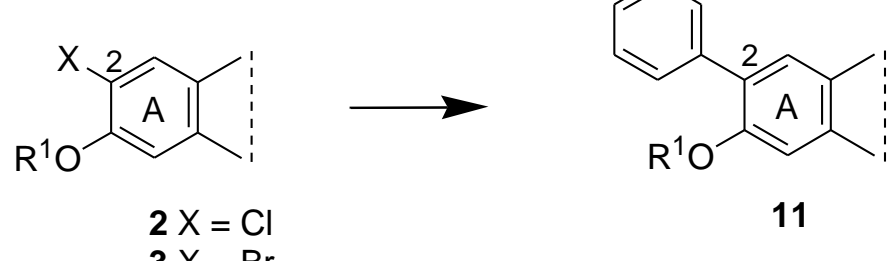

$3 X=\mathrm{Br}$

$\underbrace{A}_{X}$

$5 \mathrm{X}=\mathrm{Cl}$

$6 X=\mathrm{Br}$
$7 X=1$ \begin{tabular}{r|l}
$\mathbf{1 - 7 , 1 1 , 1 4}$ & $\mathrm{R}^{1}$ \\
\hline $\mathbf{a}$ & $\mathrm{H}$ \\
$\mathbf{b}$ & $\mathrm{Bn}$
\end{tabular}

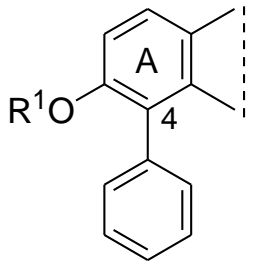

14

Scheme 3 


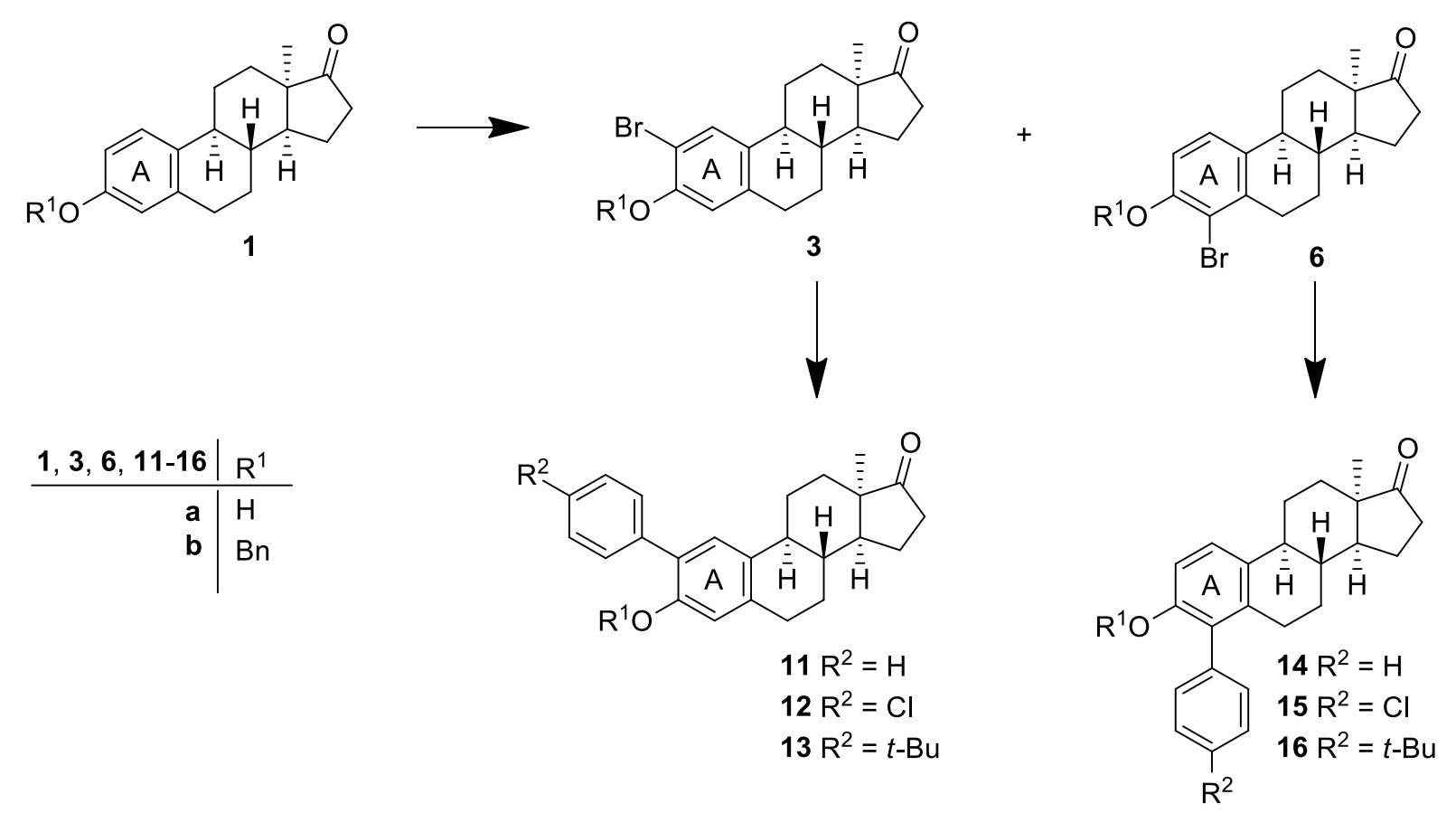

